\title{
0 Prouni e a conclusão do ensino superior: novas trajetórias pessoais e profissionais dos egressos
}

\author{
Daniela Patti do Amaral* \\ Fátima Bayma de Oliveira**
}

\section{Resumo}

Iniciamos, em 2010, a pesquisa O ProUni e o acesso ao Ensino Superior: estudo introdutório sobre os usuários do programa na zona oeste do município Rio de Janeiro, que tem por objetivo geral avaliar os impactos de uma política pública em educação voltada à inclusão no Ensino Superior privado de populações com baixas chances de acesso ao mesmo. A pesquisa, realizada entre julho de 2010 e abril de 2011, investigou dados acerca dos alunos que ingressaram no Ensino Superior em 2005 e 2006, primeiros anos do ProUni, em duas IES privadas situadas no bairro de Campo Grande, zona oeste do Rio de Janeiro. Nossa hipótese inicial foi que, após pelo menos dois anos de conclusão do curso, esses egressos já teriam construído novas trajetórias profissionais e de vida. Os dados iniciais, apesar das suas limitações, indicam que, como política pública, o ProUni tem demonstrado eficácia pela baixa taxa de evasão e que os egressos experimentaram novas trajetórias profissionais e pessoais. Palavras-chave: Políticas Públicas. ProUni. Trajetórias escolares.

\section{ProUni and the conclusion of Higher Education: the new personal and professional trajectories of the users of the Program}

\section{Abstract}

Last year we started the research ProUni and the access to Higher Education: introductory study on the users of the program in the western of the city of Rio

\footnotetext{
* Doutora em Educação, Universidade Federal do Rio de Janeiro (UFRJ); Professora Adjunta, Faculdade de Educação, UFRJ. E-mail: patti@wnetrj.com.br

** Doutora em Educação, UFRJ; Professora Titular, Fundação Getúlio Vargas (FGV/RJ). E-mail: fatima.oliveira@fgv.br
} 
de Janeiro, which aims, in general, to assess the overall impact of public policy in education geared to the inclusion of populations with low access to Higher Education private institutions. The survey, conducted between July 2010 and April 2011, investigated data related to the students who entered Higher Education in 2005 and 2006, the early years of ProUni in two private institutions located in the district of Campo Grande, in the area of Rio de Janeiro. Our initial hypothesis was that, after at least two years of graduation, these graduates would have built new trajectories in their lives and professional careers. The initial data, despite their limitations, indicate that, as public policy, ProUni has been demonstrating efficacy for the low drop-out rate and for the trajectories that graduates experienced in their new professional and personal lives.

Keywords: Public policy. ProUni. Higher Education. School trajectories.

\section{El ProUni y la conclusión de la enseñanza superior: nuevas trayectorias personales y profesionales de los egresados \\ Resumen}

Empezamos, en el año 2010, la investigación denominada el ProUni y el acceso a la educación superior: estudio introductorio sobre los usuarios del programa de la zona oeste de la ciudad de Río de Janeiro, cuyo objeto era evaluar los impactos de una política pública en educación orientada hacia la inclusión en la Enseñanza Superior privada de poblaciones con pocas oportunidades de acceso a la misma. La encuesta, realizada entre julio del 2010 y abril del 2011, analizó datos sobre los estudiantes que ingresaron a la educación superior en 2005 y 2006, primeros años del ProUni, en dos instituciones privadas situadas en el barrio de Campo Grande, zona suburbana situada al oeste de Río de Janeiro. Nuestra hipótesis inicial era que, después de dos años, por lo menos, de haber concluido el curso, los graduados ya habrían construido nuevas trayectorias profesionales y de vida. Los datos iniciales, a pesar de sus limitaciones, señalan que, como política pública, el ProUni ha demostrado su eficacia debido a la baja tasa de deserción escolar y también porque los nuevos graduados consiguieron nuevas trayectorias profesionales y personales.

Palabras clave: Politicas Públicas - ProUni - Educación superior - trayectorias escolares

\section{Introdução}

A questão da ampliação da oferta de Ensino Superior no país apresenta-se como um elemento crucial para o desenho de cenários futuros do campo educacional. Após a aprovação da Lei nº 9.394 (BRASIL, 1996), abriu-se espaço para uma nova arena no contexto do Ensino Superior como a emergência de um conjunto de instituições dos tipos mais diversos com vistas a ocupar as janelas de oportunidades 
abertas resultante da legalização de instituições de Ensino Superior com fins lucrativos; flexibilização das normas para abertura de instituições; diferenciação organizacional das instituições para melhor atender a demanda mercadológica e da implementação de cursos de curta duração.

Conforme o censo da educação superior divulgado pelo Inep (2010), dentre as 2.314 Instituições de Ensino Superior (IES) no país, apenas 186 são universidades. Os centros universitários contabilizam 127 unidades e as faculdades aparecem em maior número, totalizando 1966. Dentre esse universo de IES, 245 são públicas e 2069 privadas. 0 Ensino Superior privado, como afirmam Schwartzman e Schwartzman (2002), não é um setor homogêneo, uma vez que um número pequeno de instituições, 5\%, concentra quase a metade das matrículas do Ensino Superior privado no pais, enquanto que, no outro extremo, aproximadamente 50\% das instituições absorvem somente 5\% da matricula.

Como afirma Nunes (2007, p. 135),

do ponto de vista econômico, o setor educacional tem um porte significativo, representando um dos segmentos mais importantes do país, seja quanto à receita, seja quanto à geração de empregos. Se considerarmos apenas a educação superior, e contabilizando as rubricas e receitas próprias, transferências e outras receitas, a receita bruta total somava, em 2004, $\mathrm{R} \$ 35,483$ bilhões, sendo $\mathrm{R} \$ 19,132$ bilhões gerados pelo setor privado e $\mathrm{R} \$ 16,351$ bilhões pelo setor público.

Na tentativa de investigar uma recente política pública que permite acesso ao Ensino Superior com algumas vantagens direcionadas a determinados sujeitos, iniciamos, em 2010, a pesquisa $O$ ProUni e o acesso ao ensino superior: estudo introdutório sobre os usuários do programa na zona oeste do município Rio de Janeiro, que tem por objetivo geral avaliar os impactos de uma política pública em educação voltada à inclusão no ensino superior privado, através de bolsas de estudos, de populações com baixas chances de acesso ao ensino superior (AMARAL; OLIVEIRA, 2011). Buscamos investigar o impacto da conclusão do curso superior no bem estar dos indivíduos a partir de indicadores como renda; inserção no mundo do trabalho; ascensão profissional e os canais pelos quais os indivíduos foram afetados através de indicadores não quantitativos como motivação, autoestima e alargamento da rede social.

Barreto $(2008$, p. 9) afirma que

no processo de formulação das políticas, há que considerar os termos pelos quais o tema se traduz nos planos, programas ou projetos de governo; os objetivos a que estes se propõem; os dispositivos jurídico-normativos 
que os regulam; os recursos alocados com vistas à sua execução e as estratégias de implementação delineadas, tendo em conta as culturas institucionais em que são engendrados e as inconsistências porventura existentes em virtude das próprias dificuldades de obtenção de consensos nos processos decisórios envolvidos nessa fase. Nesse percurso, é importante atentar para os recortes, deslizamentos, mudanças de sentido, priorização de certos aspectos, omissão de outros.

A pesquisa foi realizada entre os meses de julho de 2010 e abril de 2011, e investigou dados acerca dos alunos que ingressaram no Ensino Superior em 2005 e 2006, primeiros anos do ProUni, em duas IES privadas situadas no bairro de Campo Grande, zona oeste do Rio de Janeiro. Nossa hipótese inicial foi que, em 2010, após pelo menos dois anos de conclusão do curso, esses egressos já teriam vivenciado mudanças em suas vidas profissionais e construído novas trajetórias profissionais e de vida. Cientes das limitações de nosso estudo, acreditamos, entretanto, que estamos diante de enorme desafio tanto para os formuladores de políticas públicas em educação, em especial de Ensino Superior, como para os pesquisadores e legisladores. Concluímos que há uma lacuna a ser investigada que envolve as percepções dos destinatários de uma política pública, no caso investigado o ProUni, e que há pela frente uma inesgotável fonte de investigações, problematizações e reflexões sobre os rumos que o país vêm traçando para o aumento da escolaridade da população, as políticas de ação afirmativa e a inclusão no Ensino Superior de uma população que, até pouco mais de cinco anos, tinha poucas chances de acesso a esse nível de ensino.

A ampliação do acesso ao Ensino Superior de uma população que conclui o ensino médio pretende seguir seus estudos e não encontra condições de ingresso é um dos maiores desafios educacionais para a próxima década. 0 Plano Nacional de Educação (PNE), aprovado em 2001, estabeleceu a meta de que 30\% dos jovens de 18 a 24 anos estivessem cursando esse nível de ensino no Brasil, até o final de 2010. No entanto, a Síntese dos Indicadores Sociais divulgada no final de 2009 pelo Instituto Brasileiro de Geografia e Estatística (IBGE) (2009) revelou que 13,7\% da população na faixa etária de 18 a 24 anos está matriculada na Educação Superior.

0 novo PNE 2011-2020, ainda não aprovado, no que tange ao Ensino Superior, tem como meta elevar a taxa bruta de matrícula na Educação Superior para 50\% e a taxa líquida para 33\% da população de 18 a 24 anos, assegurando a qualidade da oferta.

Com o propósito de ampliar o acesso ao Ensino Superior, o governo federal criou, em janeiro de 2005, o Programa Universidade para Todos (ProUni), através da 
Lei $n^{\circ}$. 11.096 (BRASIL, 2005). 0 Programa tem como finalidade a concessão de bolsas de estudos integrais e parciais (50\% e 25\%) a estudantes de baixa renda, em cursos de graduação e sequenciais de formação específica, em instituições privadas de educação superior, oferecendo, em contrapartida, isenção de alguns tributos àquelas IES que aderirem ao Programa.

Nessa perspectiva, Otranto (2006) revela que o ProUni se estende a todas as instituições privadas com ou sem fins lucrativos. Em troca, elas recebem isenção dos seguintes impostos: Imposto de Renda de Pessoa Jurídica, Contribuição Social sobre o Lucro Líquido, Contribuiç̧ão Social para Financiamento da Seguridade Social e Contribuição para o Programa de Integração Social. A justificativa do Ministério da Educação (MEC), autor do projeto de lei enviado ao Congresso, foi a de que a implantação desse Programa seria uma forma de criar novas vagas no Ensino Superior para alunos cotistas sem, contudo, nenhum investimento adicional por parte do governo federal, pois, como afirma Almeida (2006, p. 86), "a renúncia fiscal seria de $\mathrm{R} \$ 50$ milhões, muito inferior ao montante para gerar o mesmo número de vagas em IES públicas, estimado em $\mathrm{R} \$ 350$ milhões".

A bolsa de estudo integral é concedida a brasileiros não portadores de diploma de curso superior, cuja renda familiar mensal per capita não exceda o valor de até um salário-mínimo meio. As bolsas de estudo parciais de 50\% (cinquenta por cento) ou de $25 \%$ (vinte e cinco por cento) serão concedidas a brasileiros não-portadores de diploma de curso superior, cuja renda familiar mensal per capita não exceda o valor de até três salários-mínimos.

A bolsa será destinada a estudante que tenha cursado o ensino médio completo em escola da rede pública ou em instituições privadas na condição de bolsista integral; a estudante portador de deficiência; a professor da rede pública de ensino, para os cursos de licenciatura, Normal Superior e Pedagogia, destinados à formação do magistério da educação básica, independentemente da renda. A bolsa é um benefício concedido ao estudante pelo Governo Federal e não está condicionada a nenhuma forma de restituição monetária ao governo, ou seja, concluído o curso, o bolsista não fica devendo nada aos cofres públicos.

No seu primeiro processo seletivo, o ProUni ofereceu 112 mil bolsas em 1.142 instituições de Ensino Superior de todo o país. Desde sua criação até o processo seletivo do primeiro semestre de 2011, mais de um milhão e duzentas mil bolsas foram oferecidas, sendo que 70\% dos candidatos foram contemplados com bolsas integrais. Dentre as bolsas ofertadas, foram matriculados 748.754 estudantes. $\mathrm{Na}$ Tabela 1, apresentamos a evolução da oferta de bolsas do ProUni no país no período de 2005 até o primeiro semestre de 2011. 
Tabela 1: Evolução da oferta de bolsas do ProUni: de 2005 até o primeiro semestre de 2011.

\begin{tabular}{c|c|c|c}
\hline Ano & Parcial & Integral & Total \\
\hline 2005 & 40.370 & 71.905 & 112.275 \\
\hline 2006 & 39.907 & 98.761 & 138.668 \\
\hline 2007 & 66.223 & 97.631 & 163.854 \\
\hline 2008 & 125.510 & 99.495 & 225.005 \\
\hline 2009 & 94.517 & 153.126 & 247.643 \\
\hline 2010 & 115.351 & 125.090 & 240.441 \\
\hline 2011.1 & 42.650 & 80.520 & 123.170 \\
\hline
\end{tabular}

Fonte: Inep (2010).

A Figura 1 apresenta a evolução de ocupação das bolsas do ProUni desde a instituição do Programa.

Figura 1: Evolução de ocupação de bolsas do ProUni.

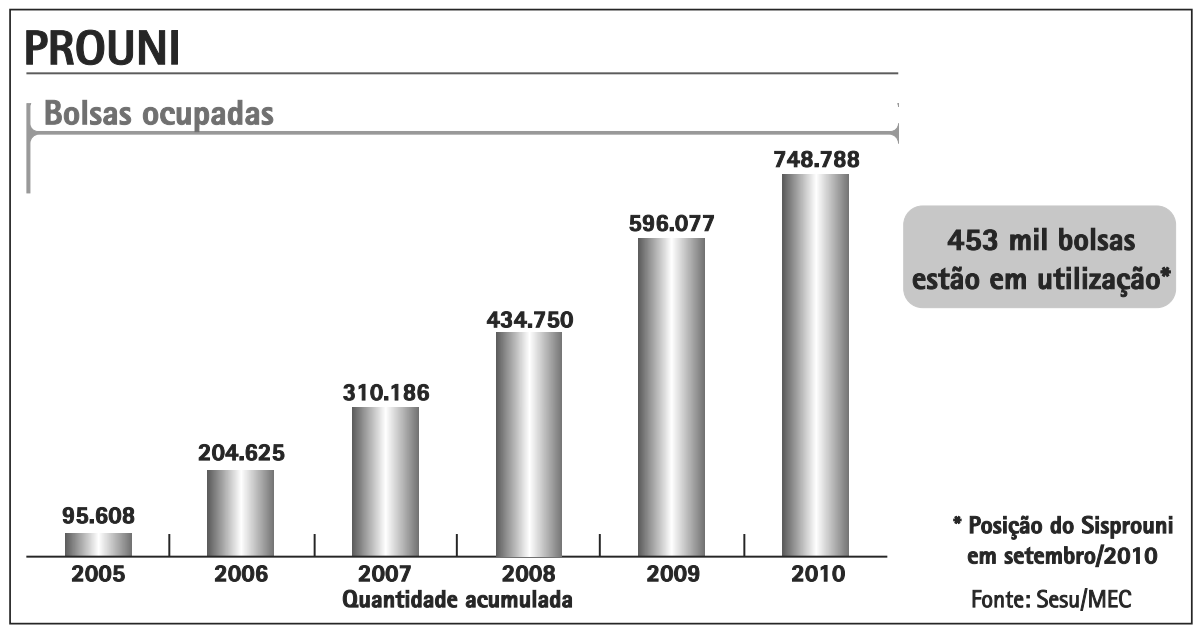

Fonte: Brasil (2010b).

Como nossa pesquisa investigou os egressos do programa no bairro de Campo Grande, é importante contextualizar essa oferta de bolsas no município do Rio de Janeiro. Destacamos que a cidade do Rio conta com algumas IES públicas ${ }^{1}$, no entanto, tem um número bem mais elevado de instituições privadas. Conforme dados disponibilizados pela Prefeitura do Rio de Janeiro (2010), a cidade do Rio de Janeiro conta com 81 IES privadas, sendo sete particulares e 74 comunitárias/filantrópicas/confessionais. Essas 81 IES privadas são potenciais candidatas a receberem

1 Universidade Federal do Rio de Janeiro (UFRJ), Universidade Federal do Estado do Rio de Janeiro (UNIRIO), Centro Universitário Estadual da Zona Oeste (UEZ0), Universidade do Estado do Rio de Janeiro (UERJ), Instituto Superior de Educação (ISE) e Centros Federais (CEFET/CEFETQ). 
bolsistas do Programa Universidade para Todos e, dentre essas, apenas sete são universidades. Entre as restantes, é possivel observar que o grupo majoritário de IES no Rio de Janeiro são faculdades, assim como no restante do pais.

Em relação à distribuição de bolsas do Programa para o município do Rio de Janeiro, os dados disponibilizados pelo MEC indicam que foram concedidas, em 2005, 5.908 bolsas sendo 1.695 parciais e 4.213 integrais. Em 2006, o Programa distribuiu para o município 6.994 bolsas, sendo 422 parciais e 6.572 integrais. Como nossa pesquisa visa a problematizar os dados sobre os primeiros bolsistas do ProUni, limitamos nossa busca aos dados desses dois anos. 0 Quadro 1 oferece um panorama da distribuição das bolsas do ProUni no município do Rio de Janeiro nos primeiros anos do programa em relação ao estado do Rio de Janeiro e a todo território nacional.

Quadro 1: Bolsas ofertadas no Município e no Estado do Rio de Janeiro: total geral em todo território nacional.

\begin{tabular}{|c|c|c|c|c|}
\hline \multirow{2}{*}{ Município } & Ano & \multicolumn{3}{|c|}{ Números de bolsas ofertadas } \\
\hline & \multirow{4}{*}{$\begin{array}{l}2 \\
0 \\
0 \\
5\end{array}$} & Integral & Parcial & Total \\
\hline Rio de Janeiro & & 4.213 & 1.695 & 5.908 \\
\hline $\begin{array}{l}\text { Nos demais Municípios } \\
\text { do Rio de Janeiro }\end{array}$ & & 2.184 & 1.357 & 3.541 \\
\hline Total Geral & & 71.905 & 40.370 & 112.275 \\
\hline Rio de Janeiro & 2 & 6.572 & 422 & 6.994 \\
\hline $\begin{array}{l}\text { Nos demais Municípios } \\
\text { do Rio de Janeiro }\end{array}$ & $\begin{array}{l}0 \\
0\end{array}$ & 5.152 & 1.093 & 6.425 \\
\hline Total Geral & 6 & 98.698 & 39.970 & 138.668 \\
\hline
\end{tabular}

Fonte: Rio de Janeiro (2010).

Buscamos investigar de que forma se deu a trajetória escolar dos bolsistas do ProUni em duas IES privadas da zona oeste do município do Rio de Janeiro, especificamente no bairro de Campo Grande. Observa-se que a oferta de vagas em IES públicas no bairro de Campo Grande é incipiente. A universidade pública mais próxima ao território selecionado para pesquisa é a Universidade Federal Rural do Rio de Janeiro que fica a aproximadamente $25 \mathrm{~km}$ de distância, no municipio de Seropédica. 0 bairro de Campo Grande conta, atualmente, com cinco IES privadas, sendo uma universidade, dois centros universitários e duas faculdades. Conforme dados da prefeitura (RIO DE JANEIRO, 2010), no ano 2000 havia 8.795 moradores de Campo Grande matriculados no ensino superior em nivel de graduação. Campo Grande é a região com o maior contingente populacional da cidade onde residem, aproximadamente, 900 mil habitantes segundo Censo 2000 do IBGE. A extensão de seu território, o grande contingente populacional, baixo índice de desenvolvimento humano e a incipiente oferta de vagas em instituiç̧ões públicas de ensino superior tornam a região de Campo 
Grande um terreno fértil para a oferta de ensino superior privado e potenciais bolsistas do ProUni, escolhida, nesse sentido, como universo para nossa investigação.

\section{0 desenvolvimento da pesquisa}

Teixeira (2005) afirma que, a partir dos anos 70 do século passado, houve um considerável crescimento de interesse na pesquisa qualitativa ou interpretativa. Nesse tipo de trabalho, o pesquisador procura reduzir a distância entre a teoria e os dados, entre o contexto e a ação, buscando compreender também as circunstâncias que envolvem determinada situação.

Em relação aos procedimentos metodológicos desenvolvidos para responder às questões norteadoras da pesquisa, são esclarecedoras as considerações de Luna (1997, p. 28), quando diz que esses procedimentos constituem "[...] um conjunto de passos que gerem informação relevante [...] nenhuma metodologia pode dispensar procedimentos". Minayo $(2007$, p. 14) apresenta ponto de vista coerente com o de Luna ao salientar que metodologia é "[...] o caminho do pensamento e a prática exercida na abordagem da realidade". Por isso, segundo a autora, a metodologia é muito mais que técnicas. "Ela inclui as concepções teóricas de abordagem, articulando-se com a teoria, com a realidade empírica e com os pensamentos sobre a realidade [...] nada substitui, no entanto, a criatividade do pesquisador" (MINAYO, 2007, p. 15). Optamos por uma abordagem qualitativa do objeto da pesquisa, uma vez que procuramos analisar o impacto de uma recente política pública no campo da Educação Superior brasileira e nosso objeto recaiu na investigação sobre dados e percepções dos primeiros bolsistas do ProUni.

Nesse sentido, coletamos, inicialmente, os dados quantitativos sobre os primeiros bolsistas do ProUni que ingressaram em 2005 e 2006 em duas IES localizadas no bairro de Campo Grande e, em um segundo momento, procuramos entrar em contato com os egressos e investigar o impacto da conclusão do curso superior no bem estar desses indivíduos a partir de indicadores como renda, inserção no mundo do trabalho, ascensão profissional e os canais pelos quais os indivíduos foram afetados através de indicadores não quantitativos como motivação, autoestima e alargamento da rede social. Os dados sobre os bolsistas nos dois primeiros anos do Programa (2005 e 2006) foram coletados entre os meses de setembro de 2010 e fevereiro de 2011.

Mais uma vez, apoiamo-nos em Minayo (2007), quando argumenta que a pesquisa qualitativa nas ciências sociais se preocupa com um nível de realidade que não pode ou não deveria ser quantificado. Isso significa que ela trabalha com o universo dos significados, dos motivos, das aspirações, das crenças, dos valores e das atitudes. $E$, conforme a autora, esse conjunto de fenômenos humanos é entendido aqui como parte da realidade social, pois o ser humano se distingue não só por agir, mas por pensar sobre o que faz e por interpretar suas ações dentro e a partir da realidade vivida e partilhada com seus semelhantes" (MINAYO, 2007, p. 21).

A escolha de um determinado método interfere nas relações estabelecidas com 
o objeto que se pretende conhecer desde o levantamento das questões a serem respondidas até o modo como tratamos o referido objeto e empreendemos as respostas conferidas na investigação do mesmo. 0 problema da pesquisa não está somente na escolha de um método, mas envolve o problema do conhecimento. Este sim é o terreno da pesquisa de onde emergem as decisões que dão sustentação às práticas relativas ao trato com o objeto.

0 conhecimento humano se torna um fenômeno humano, do qual o erro, a imprecisão, a generalização indevida nunca estão inteiramente ausentes. 0 conhecimento, sempre perfectivel, é sempre imperfeito. A verdade não é coincidência perfeita com o seu objeto [...] o conhecimento se torna situado no meio cultural, na tradição, na disciplina. A história do conhecimento deixa de ser história dos erros da mente humana para se tornar a de seus progressos (PERELMAN, 1999, p. 365-366).

De certo que a pesquisa realizada, apesar de relevante, apresenta limitações. $\mathrm{Na}$ fundamentação teórico empírica, ainda são poucos os estudos acerca da percepção dos destinatários de uma política pública em educação e, no caso específico desse artigo, dos usuários do Programa Universidade para Todos. Serão necessários novos estudos, em larga escala, para que se possa desenhar um cenário dos impactos do ProUni na sociedade brasileira. No que diz respeito à busca dos egressos, esbarramos em questões éticas como a não divulgação por parte da IES dos contatos dos alunos - endereço de e-mail e/ou telefones. Quando isso se efetivou, muitos desses contatos já não eram mais utilizados pelos ex-alunos: e-mails desativados e/ou telefones que já não existiam. Isso, todavia, não impediu que conseguíssemos utilizar as redes sociais disponiveis na Internet como mecanismo de busca e aproximação dessas pessoas.

\section{Dados sobre a Instituição de Ensino Superior pesquisada IES “A”}

A primeira IES investigada é uma faculdade com cinquenta anos de história no bairro de Campo Grande e que foi concebida no final da década de 50 do século passado para ser uma instituição de Ensino Superior voltada para a formação de professores, algo inédito na região naquele tempo. Atualmente, entre os nove cursos oferecidos nessa IES, oito são licenciaturas, integralizados em sete semestres. A IES oferece somente um bacharelado em Sistemas de Informação com quatro anos de duração. Nesse sentido, a instituição mantém sua trajetória marcada pela formação professores. Como a maioria dos cursos é integralizada em três anos e meio, espera-se que os bolsistas que ingressaram nos anos de 2005 e 2006 já tenham completado o curso superior e, de certa forma, construído uma nova trajetória de inserção no mundo do trabalho entre os anos de 2007 e 2010. Todos os bolsistas que ingressaram nesses anos foram contemplados com bolsa integral. 
Em 2005, ingressaram na instituição, como bolsistas do ProUni, 114 alunos, sendo que 111 estudavam em cursos noturnos e somente três em cursos vespertinos. Noventa e nove estavam em diferentes licenciaturas ${ }^{2}$ e 15 no bacharelado ${ }^{3}$. Noventa e dois concluíram o curso; sendo 80 licenciados e 12 bacharéis, o que corresponde a uma taxa de evasão de 19\%. Dentre os concluintes, oitenta e nove frequentavam cursos noturnos e somente três estavam matriculados em cursos no turno da manhã. Destacamos que os cursos noturnos são significativamente mais procurados pelos bolsistas (97\%) e a taxa de evadidos não apresenta discrepância considerável entre os cursos, estando relativamente semelhante.

Na Tabela 2 apresentamos os dados do ano de 2005 contemplando os ingressantes com bolsas do ProUni.

Tabela 2: IES "A": ano de ingresso 2005.

\begin{tabular}{l|c|c|c|c}
\hline Curso & Turno & Ingressantes & Evadidos & Concluintes \\
\hline Ciências Sociais & Noturno & 11 & 2 & 9 \\
\hline Computação & Noturno & 7 & 1 & 6 \\
\hline Geografia & Noturno & 14 & 2 & 12 \\
\hline História & Noturno & 17 & 3 & 14 \\
\hline Sistemas de informação & Noturno & 15 & 3 & 12 \\
\hline Letras (Espanhol) & Noturno & 12 & 4 & 8 \\
\hline Matemática & Noturno & 11 & 2 & 9 \\
\hline Pedagogia & Noturno & 10 & 1 & 9 \\
\hline Letras (Lingua Portuguesa) & Noturno & 11 & 1 & 10 \\
\hline Letras (Francês) & Noturno & 3 & 3 & 0 \\
\hline Letras (Lingua Portuguesa) & Matutino & 2 & 0 & 2 \\
\hline Matemática & Matutino & 1 & 0 & 1 \\
\hline Total & Noturno & 111 & 22 & 89 \\
\hline Total & Matutino & 3 & 0 & 3 \\
\hline Total Geral & & 114 & 22 & 92 \\
\hline
\end{tabular}

Fonte: Rio de Janeiro (2010)

No segundo ano de vigência do ProUni, ingressaram 39 alunos, e 29 concluíram seus cursos, o que corresponde a uma taxa de evasão de 26\%. Trinta e oito alunos estavam matriculados em cursos noturnos e somente uma matrícula era de curso matinal. Todos cursavam licenciaturas. Na Tabela 3, apresentamos os dados do ano de 2006, contemplando os ingressantes com bolsas do ProUni. 
Tabela 3: IES "A": ano de ingresso 2006.

\begin{tabular}{l|c|c|c|c}
\hline Curso & Turno & Ingressantes & Evadidos & Concluintes \\
\hline Ciências Sociais & Noturno & 5 & 3 & 2 \\
\hline Computação & Noturno & 2 & 0 & 2 \\
\hline Geografia & Noturno & 5 & 4 & 1 \\
\hline História & Noturno & 5 & 1 & 4 \\
\hline Letras (Espanhol) & Noturno & 5 & 0 & 5 \\
\hline Matemática & Noturno & 5 & 1 & 4 \\
\hline Pedagogia & Noturno & 6 & 0 & 6 \\
\hline Letras (Língua Portuguesa) & Noturno & 5 & 1 & 4 \\
\hline Pedagogia & Matutino & 1 & 0 & 1 \\
\hline Total & Noturno & 38 & 10 & 28 \\
\hline Total & Matutino & 1 & 0 & 1 \\
\hline Total Geral & & 39 & 10 & 29 \\
\hline Fonte: Rio de Janeiro & & & &
\end{tabular}

Fonte: Rio de Janeiro (2010).

Gatti e Barreto $(2009$, p. 68) indicam que os cursos noturnos, de modo geral, tendem a ter um funcionamento mais precário do que os diurnos, particularmente no que diz respeito às atividades ligadas às práticas docentes requeridas pela formação específica para o magistério. Para as autoras, a formação dos estudantes de licenciatura, realizada no período noturno, tende a ocorrer em condições de qualidade menos satisfatórias que a dos demais licenciandos. Conforme o Censo da Educação Superior do Instituto Nacional de Estudos e Pesquisa (Inep) de 2009, dentre todas as matrículas no Ensino Superior em 2009, 63\% estão concentradas em cursos noturnos. Zago (2010) destaca que o trabalhador/estudante dos cursos noturnos vivencia, quotidianamente, a divisão social do trabalho e, como trabalhador, adquire um conhecimento muito além do necessário para a execução as tarefas que Ihe são confiadas.

\section{Dados sobre a Instituição de Ensino Superior pesquisada IES “B”}

A coleta de dados nessa instituição foi mais demorada e, por diferentes fatores, não obtivemos todas as informações necessárias para o desenvolvimento da pesquisa. Essa instituição, diferentemente da IES "A", é um centro universitário, logo, goza de maior autonomia institucional e oferece um número maior de cursos de graduação. Criada no final da década de sessenta do século passado, a instituição oferece, atualmente, 14 cursos de graduação $0^{4}$.

4 Bacharelados em Sistemas da Informação; Administração, Ciências Contábeis; Comunicação Social, Direito, Engenharia de Produção, Fisioterapia; e Licenciaturas em Física; Geografia, História, Letras; Matemática; Pedagogia e Educação Física. 
Conforme as informações coletadas junto à instituição, em 2005, ingressaram 72 bolsistas do ProUni com bolsa integral e 27 com bolsa parcial totalizando 99 bolsistas, sendo que, dentre esses, 50 estavam matriculados em cursos de licenciatura. No entanto, não foi possivel obter a informação sobre os turnos. Dentre o total de 99 ingressantes, 87 concluíram o curso superior o que equivale a 87\% de êxito escolar. Comparando os dados dos alunos com bolsa integral e parcial, não se observa muita diferença uma vez que o êxito dos alunos beneficiados com bolsa integral foi de $86 \%$ e dos beneficiados com bolsa parcial foi de 92\%.

Uma observação que gostariamos de destacar é a ausência de fracasso escolar entre os bolsistas das licenciaturas - não há evadidos em nenhum desses cursos. Entre os bacharelados, o único em que não há evasão é o curso de Fonoaudiologia que contou com apenas quatro bolsistas.

$\mathrm{Na}$ Tabela 4, apresentamos os dados referentes aos bolsistas que ingressaram na IES "B" no ano de 2005.

Tabela 4: IES "B": ano de ingresso 2005.

\begin{tabular}{l|c|c|c|c|c|c}
\hline \multirow{2}{*}{ Curso } & \multicolumn{3}{|c|}{ Bolsa Integral } & \multicolumn{3}{c}{ Bolsa Parcial } \\
\cline { 2 - 7 } & Ingressos & Suspensas & Encerradas & Ingressos & Suspensas & Encerradas \\
\hline Administração & 13 & 1 & 12 & 4 & 2 & 2 \\
\hline Com. Social & 6 & 2 & 4 & 3 & -- & 3 \\
\hline Direito & 8 & 3 & 5 & 1 & -- & 1 \\
\hline Ed. Física & 8 & -- & 8 & 1 & -- & 1 \\
\hline Física & 4 & -- & 4 & 3 & -- & 3 \\
\hline Fisioterapia & 6 & 2 & 4 & 2 & -- & 2 \\
\hline Fonoaudiologia & 3 & -- & 3 & -- & -- & -- \\
\hline Geografia & 4 & -- & 4 & 2 & -- & 2 \\
\hline História & 6 & -- & 6 & 3 & -- & 3 \\
\hline Letras & 5 & -- & 5 & 3 & -- & 3 \\
\hline Matemática & 3 & -- & 3 & 3 & -- & 3 \\
\hline Pedagogia & 3 & -- & 3 & 2 & -- & 2 \\
\hline Sis. Informação & 3 & 2 & 1 & -- & -- & -- \\
\hline TOTAL & 72 & 10 & 62 & 27 & 2 & 25 \\
\hline
\end{tabular}

Fonte: Rio de Janeiro (2010).

No segundo ano de oferta de bolsas do ProUni, essa IES concedeu 45 bolsas sendo 31 integrais e 14 parciais. Dentre os beneficiados com bolsa integral, 25 concluíram o curso o que corresponde a $80 \%$ do total. Em relação aos alunos contemplados com bolsa parcial, 85\% deles obtiveram sucesso ao completar o curso superior. Os dados podem ser observados na Tabela 5. 
Tabela 5: IES "B": ano de ingresso 2006.

\begin{tabular}{l|c|c|c|c|c|c}
\hline \multirow{2}{*}{ Curso } & \multicolumn{3}{|c|}{ Bolsa Integral } & \multicolumn{3}{c}{ Bolsa Parcial } \\
\cline { 2 - 7 } & Ingressos & Suspensas & Encerradas & Ingressos & Suspensas & Encerradas \\
\hline Administração & 2 & 1 & 1 & 1 & -- & 1 \\
\hline Com. Social & 1 & -- & 1 & -- & -- & -- \\
\hline Direito & 1 & 1 & -- & 1 & -- & 1 \\
\hline Ed. Física & 9 & 1 & 8 & 3 & -- & 3 \\
\hline Física & -- & -- & -- & -- & -- & -- \\
\hline Fisioterapia & 5 & 2 & 3 & 4 & 1 & 3 \\
\hline Fonoaudiologia & -- & -- & -- & -- & -- & -- \\
\hline Geografia & 3 & -- & 3 & 1 & 1 & -- \\
\hline História & 4 & -- & 4 & 2 & -- & 2 \\
\hline Letras & -- & -- & -- & -- & -- & -- \\
\hline Matemática & 6 & 1 & 5 & 1 & -- & 1 \\
\hline Pedagogia & -- & -- & -- & 1 & -- & 1 \\
\hline Sis. Informação & -- & -- & -- & -- & -- & -- \\
\hline TOTAL & 31 & 6 & 25 & 14 & 2 & 12 \\
\hline
\end{tabular}

Fonte: Rio de Janeiro (2010).

Em 2006, das 45 bolsas oferecidas, 22 ou 50\% delas estavam alocadas em licenciaturas. Desse total, apenas três alunos evadiram o que corresponde a uma taxa de sucesso escolar de $86 \%$.

Se contabilizarmos os bolsistas da IES A que concluíram licenciaturas temos um total de 80 e, na IES B, 75 alunos concluíram as licenciaturas, o que corresponde a 155 novos professores no mercado do trabalho beneficiados pelo ProUni.

Observamos que, em ambas as instituições de ensino, houve uma oferta menor de bolsas no segundo ano do programa apesar da oferta do MEC, destacada na Tabela 1, demonstrar que foram oferecidas 26 mil bolsas a mais do que no primeiro ano do programa. Esse é um dado que exige novas investigações acerca da demanda, da procura e da divulgação das bolsas por parte das IES.

A Receita Federal estima que o ProUni dará isenção de 510 milhões de reais às instituições com fins lucrativos em 2011. A isenção das demais instituições - sem fins lucrativos e beneficentes - não é divulgada separadamente já que entra no bolo de outras isenções que independem do ProUni (BOLSAS..., 2011).

\section{Os egressos do ProUni e suas novas trajetórias}

Zago (2010) destaca que, nas camadas populares, embora a maioria ingresse na escola conforme os ditames previstos, isto é, aos seis ou sete anos 
de idade, geralmente a continuidade do percurso transcorre de forma oposta ao tipo considerado ideal, ou seja, a adequação idade-sére a finalização do ensino fundamental aos 14 ou 15 anos de idade. A autora destaca que após análise de diversas histórias escolares, observou-se que vários estudantes detinham um nível de escolaridade incompativel com o tempo que permaneceram vinculados ao sistema escolar indicando um percurso escolar " fortemente acidentado". A autora conclui que a "escolaridade não obedece ao tempo normal de entrada e permanência até a finalização de um ciclo escolar, mas se define no tempo do possível" (ZAG0, 2010, p. 25).

É preciso, entretanto, compreender que as escolhas feitas pelos estudantes de classes populares acerca de sua escolarização em nivel superior nem sempre estão pautadas na qualidade de oferta do ensino pelas instituições tampouco na escolha pelo curso desejado, mas, no que é possível estudar e aonde é possível se matricular. Ratificando o que já foi destacado anteriormente, a oferta de Ensino Superior público, considerado pela sociedade brasileira como de qualidade, é incipiente no bairro de Campo Grande. E, ainda, o acesso às IES públicas, em especial às universidades federais, historicamente foi pautado por dificuldades devido aos exames vestibulares complexos, pelo elevado número de candidatos e pela disputada relação candidato/vaga em muitos cursos. Como afirmado por Bourdieu (1998), a competência exigida pela escolha das melhores estratégias objetivas como a de um estabelecimento escolar é repartida de modo desigual uma vez que varia quase exatamente como o poder do qual depende o êxito dessas estratégias.

Nesse sentido, afirma Bourdieu (1998, p. 94),

não dispondo de informações suficientemente atualizadas para conhecer a tempo as "apostas" a serem feitas, nem de um capital econômico suficientemente importante para suportar a espera incerta dos ganhos financeiros, nem tampouco de um capital social suficientemente grande para encontrar uma saída alternativa em caso de fracasso, as famílias das classes populares e médias (ao mesmo nas frações não assalariadas) tem todas as chances de fazerem maus investimentos escolares.

Ainda conforme Bourdieu (1998), é possivel observar nas oportunidades de acesso ao Ensino Superior o resultado de uma seleção direta ou indireta que, ao longo da escolaridade, pesa com rigor desigual sobre os sujeitos das diferentes classes sociais. 0 autor afirma que "um jovem da camada superior tem oitenta vezes mais chances de entrar na Universidade que o filho de um assalariado agrícola e quarenta vezes mais que um filho de operário" (BOURDIEU, 1998, p. 410). 
Em nossa busca pelos ex-bolsistas do programa, após incansáveis tentativas de contato, recebemos somente seis questionários respondidos. Todos os respondentes são egressos da IES "A". Em relação aos dados gerais coletados, quatro respondentes são do sexo feminino e dois do sexo masculino com as seguintes idades: 25 (masculino); 26 (masculino); 23 (feminino); 24 (feminino); 38 (feminino); e 53 (feminino). Os bairros em que residem são: Senador Vasconcelos; Penha; Ibicuí; Campo Grande (dois) e Santíssimo.

Todos os respondentes são egressos da rede pública estadual de ensino onde cursaram o ensino médio. 0 ano de conclusão do ensino médio de cinco dos respondentes variava entre 2001 (um respondente); 2003 (dois respondentes) e 2004 (dois respondentes). A respondente de mais idade concluiu o ensino médio em 1976. Entre os cursos concluidos na IES "A" estão: Matemática; Geografia; Pedagogia (dois); Licenciatura em Computação e História. Todos tiveram bolsa integral, concluiram o Curso Superior no prazo regular e estudaram em cursos noturnos. Um estudante colou grau em 2009, dois em 2008 e três em 2007.

Os contatos foram realizados por e-mail e os seis egressos (aqui denominados respondentes $A, B, C, D, E, F$ ) responderam a um questionário em que se buscaram informações acerca da conclusão do Ensino Superior, das novas inserções profissionais, do alargamento da rede social e da escolarização. Destacamos, a seguir, as falas dos egressos acerca de questões sobre trabalho, renda, alargamento da rede social, entre outras.

\section{Percepções sobre os efeitos da conclusão do Curso Superior}

\section{Você está trabalhando e em que área?}

Acerca das percepções sobre os efeitos da conclusão do Ensino Superior, somente um respondente (respondente "B", sexo masculino, 26 anos; licenciado em Geografia em 2009) não estava trabalhando no momento da coleta de dados.

0 respondente "A", do sexo masculino, 25 anos, que concluiu a licenciatura em Matemática em 2007, é Técnico em Assuntos Educacionais na Universidade Federal do Rio de Janeiro (UFRJ), admitido por concurso público em 2010, sendo que pediu exoneração de duas matrículas como professor da rede estadual no estado do Rio de Janeiro. Conforme o respondente, o salário na UFRJ, onde atua no setor de pessoal do Instituto de Física, é maior do que o que recebia em duas matrículas na rede estadual e, por atuar, mesmo que administrativamente, na área de Física, acredita que terá chances de transitar em sua área de formação e, futuramente, candidatar-se ao mestrado. Não podemos nos furtar de comentar esse fato. Um professor, com duas matrículas na rede estadual do Rio de Janeiro ganha, em média, $\mathrm{R} \$ 1.500,00$ por mês para uma jornada de trabalho de 32 horas semanais. Para uma jornada de 40 horas, com maior flexibilidade de horário e menor responsabilidade, a função que ele exerce na UFRJ tem uma remuneração em torno de $\mathrm{R} \$ 2$ mil reais. Como seduzir um profes- 
sor recém formado a atuar em sala de aula diante dessa realidade e diante da realidade das salas de aula atualmente? Nessa situação, o magistério funcionou como um "quebra-galho" ou uma atividade provisória até o aparecimento de alguma coisa melhor, o que, no caso em questão, aconteceu, segundo a percepção do respondente.

A respondente " $\mathrm{C}$ ", sexo feminino, 23 anos, licenciou-se em Pedagogia em 2008 e atualmente é técnica de atendimento social no programa Delegacia Legal.

A respondente "D", sexo feminino, 24 anos, concluiu em 2007 a licenciatura em Computação e trabalha atualmente como analista de sistemas em uma rede hospitalar.

A respondente "E", sexo feminino, 38 anos, licenciada em Pedagogia em 2007, é concursada pela Secretaria Estadual de Educação e atua como professora-inspetora escolar.

A respondente "F", licenciada em História em 2008, atua como professora em uma escola municipal.

\section{A sua formação ampliou as oportunidades de emprego e trouxe melhoria na qualidade de vida?}

Somente o respondente " $B$ ", que não está trabalhando, respondeu 'não' a esta pergunta. Os outros cinco respondentes, que disseram que a sua formação ampliou as oportunidade emprego e trouxe melhoria na qualidade de vida, fizeram as seguintes afirmações:

"Ampliou bastante as oportunidades de emprego e felizmente
consegui passar no concurso para professor logo após a con-
clusão do curso. A decisão de mudança e área se deu pela
dificuldade que o professor enfrenta hoje em dia com o aluno,
além de desrespeito e outros fatores" (respondente A).
"Levando em consideração meu atual emprego, onde é
necessário ser formada no Ensino Superior, houve sim uma
melhoria na minha qualidade de vida, pois minha carga
horária é muito boa e o salário razoável" (respondente C).
"Pois possibilitou um conhecimento mais profundo na área
de Informática na qual forneceu a oportunidade de um
crescimento profissional considerável" (respondente D).
"A função que desempenhava anteriormente, trabalhador
informal, exigia grande desgaste fisico e psicológico o que
comprometeu minha saúde física e mental" (respondente E).
"Trouxe melhoria na qualidade de vida, pois aumentou o
meu piso salarial e subi de classe e nivel" (respondente F).

Observa-se, pelas informações fornecidas pelos ex-bolsistas, que a quase totalidade deles está empregada e percebeu ampliação das oportunidades de empregabilidade e melhoria na qualidade e vida e renda. Dois foram aprovados em concurso 
público, o que é extremamente simbólico na sociedade brasileira como garantia de estabilidade, em especial se tratando de famílias de baixa renda.

\section{Sua renda melhorou após a conclusão do curso?}

Novamente, somente o respondente "B", que não está trabalhando, respondeu que não observou melhoria na renda. Os outros cinco respondentes afirmaram que a renda melhorou após a conclusão do curso:

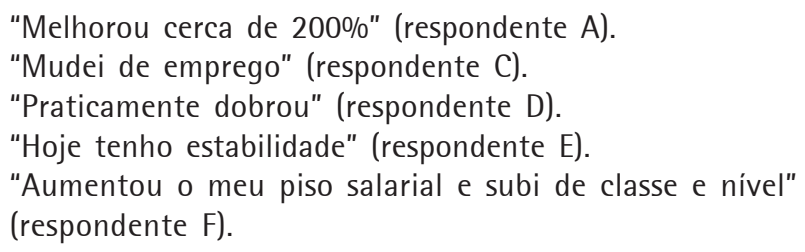

Nesse contexto, as respostas coadunam-se com a pesquisa encomendada pelo MEC ao Instituto Brasileiro de Opinião Pública e Estatística (Ibope) e realizada no período de 13 a 23 de março e 2009 com dados divulgados em maio de 2009 no endereço eletrônico do MEC. Conforma a pesquisa, profissionais formados com bolsas integrais do ProUni revelaram que o mercado de trabalho se abriu - 80\% estão trabalhando -, e que a renda familiar aumentou para $68 \%$ deles e, destes, $28 \%$ relatam que melhorou muito.

\section{Você teve maior facilidade de conseguir trabalho/emprego após a conclusão do Curso Superior?}

Três respondentes afirmaram que não tiveram maior facilidade de conseguir trabalho/emprego após a conclusão do Curso Superior. 0 respondente $B$, que não está trabalhando no momento, uma vez mais respondeu negativamente a essa pergunta.
"Já era funcionária da prefeitura de Nova Iguaçu quando comecei a graduação" (respondente F).
"Ao menos onde mantenho residência não, pois por ser interior são poucas empresas e as maiores quantidades de vagas em minha graduação são da prefeitura onde só se entra por indicação" (respondente C).

Cabe destacar que a respondente $C_{1}$ em várias ocasiões, apesar de enaltecer a ampliação de oportunidades após a conclusão do curso e a mudança e emprego, afirma esbarrar em um grande obstáculo que é a localidade onde mora, carente de maiores investimentos, recursos e oportunidades de trabalho. Já os outros três respondentes afirmaram que

"As oportunidades que apareceram, todas me saí muito bem graças aos conhecimentos adquiridos durante a graduação" (respondente D).

"Dias depois da conclusão fiz a prova do concurso tendo sido convocada para atuar três meses depois" (respondente E.) 
"Possuía mais conteúdo para encarar um concurso público, quanto ao emprego privado, estava um pouco em desvantagem levando em consideração que escolas particulares não estão muito abertas a professores novos em todos os sentidos" (respondente A).

Analisando os dados, observa-se que a respondente $F$, além de ser bem mais velha que os outros respondentes, já estava empregada antes da graduação sendo que o Curso Superior trouxe ascensão profissional no plano de carreira da rede municipal em que atua. Já os respondentes $D, E$ e $A$ concordaram que a conclusão do Curso Superior abriu uma janela de oportunidades.

\title{
Você teve algum tipo de ascensão profissional após a conclusão do curso?
}

Dois respondentes afirmaram que não tiveram ascensão profissional:

\begin{abstract}
"Por enquanto estou em busca de oportunidade em minha área (respondente $\mathrm{B}$ ).

"Apenas mudei de emprego e função, pois meu atual emprego não tem expectativa de crescimento profissional" (respondente $\mathrm{C}$ ).
\end{abstract}

No entanto, quatro respondentes fizeram afirmações positivas sobre essa questão:

"Antes de concluir o curso trabalhava informalmente. Atualmente ocupo um cargo público estadual, com estabilidade e possibilidade de ascensão salarial" (respondente E). "Trabalhei como professora na área educacional durante um tempo, após concluir a segunda graduação trabalhei como assistente na área hospitalar, e dentro de pouco tempo me tornei analista" (respondente D).

"Agora na escola onde trabalho sou coordenadora de aprendizagem do horário integral onde atuo com estagiários universitários e de ensino médio" (respondente F).

"Apenas quanto a minha qualificação profissional" (respondente A).

Como afirma Bourdieu (1998), a chegada ao Ensino Superior, considerada aqui como uma trajetória de "sucesso escolar", mesmo que por meio de uma política pública de ação afirmativa poderá aumentar o capital social do indivíduo. 0 autor afirma que

o capital social é o conjunto de recursos atuais ou potenciais que estão ligados à pose de uma rede durável de relações mais ou menos institucionalizadas de inter-reconhecimento e de inter-reconhecimento ou, em outros termos, à vinculação a um grupo, como conjunto de 
agentes que não somente são dotados de propriedades comuns, mas também são unidos por ligações permanentes e úteis [...] o volume do capital social que um agente individual possui depende então da extensão da rede de relações que ele pode efetivamente mobilizar e do volume do capital (econômico, cultural e simbólico) que é posse exclusiva de cada um daqueles a quem está ligado (BOURDIEU, 1998, p. 67).

\section{Sentiu mudanças na sua motivação e autoestima?}

Dentre os seis respondentes, apenas um afirmou que não percebeu mudanças em sua motivação e autoestima:

"por ser realista e não ter cursado o Ensino Superior que desejava" (respondente C).

A fala do ex-bolsista encontra suporte no que já mencionamos anteriormente acerca das escolhas feitas pelos estudantes de classes populares sobre sua escolarização em nível superior, nem sempre pautadas na vocação ou no desejo, mas, no que é possivel estudar e aonde é possível se matricular, criando, assim, uma "nova vocação" profissional a partir do plausivel e não do desejável.

Zago (2010) destaca, nesse contexto, que, quando não é possível investir no ensino que se acredita ser de melhor qualidade e mais rentável profissionalmente, opta-se pelo que é viável. A opção, nesse caso, é por um curso que condiz com as atividades do aluno trabalhador e representa menor risco de fracasso escolar.

Os outros cinco respondentes mostraram-se motivados:

"porque agora trabalho com mais segurança" (respondente F). "sempre foi um sonho concluir um Curso Superior, mas a falta de dinheiro sempre foi um problema, graças ao ProUni consegui realizar esse sonho" (respondente D).

"sinto-me motivada a dar continuidade aos estudos, na certeza da igualdade de oportunidades advindas de meu esforço e dedicação, independente de minha classe social" (respondente E).

"Sim! Concluir o Ensino Superior fez com que eu me sentisse mais autoconfiante, ou seja, apesar das dificuldades eu cheguei lá! E a sensação de que minha escolha pode contribuir com a melhoria nas condições de vida de minha família faz com que eu me sinta meIhor" (respondente B).

"Você se sente mais motivado e capacitado" (respondente A). 
Observou algum alargamento da rede social?

Dois respondentes afirmaram 'não observar alargamento na rede social', sendo que o respondente $A$ não justificou sua resposta:

"Não percebi nenhuma mudança" (respondente C).

No entanto, os outros quatro respondentes falaram de maneira positiva sobre essa indagação:

\begin{abstract}
"Pois agora viajo de três a quatro vezes por ano para conhecer cidades históricas do Brasil" (respondente F). "Aumento do leque de culturas e conhecimentos, pessoas as quais me relaciono atualmente" (respondente D).

"Alargamento quantitativo e qualitativo. Atualmente tenho contato como os demais colegas de cargo da SEEDUC/RJ, assim como participo de Seminários, plenárias do ConseIho Estadual de Educação, representantes legais de escolas de pequeno, médio e grande porte" (respondente E).

"Através da universidade pude conhecer pessoas que compartilham os mesmo interesses que o meu, e também pessoas com interesses diferentes. Além de um maior contato com pessoas de outras classes sociais" (respondente B).
\end{abstract}

\title{
Alguém da sua família se sentiu motivado a iniciar ou prosseguir os estudos?
}

Dentre os respondentes, dois afirmaram que nenhum membro da família se sentiu motivado a iniciar ou dar prosseguimento aos estudos, sendo que o responde A não justificou sua escolha.

"Como comentado anteriormente, onde moramos não há muitas oportunidades para pessoas formadas e qualificadas" (respondente C).

Os outros quatro respondentes da pesquisa afirmaram que:

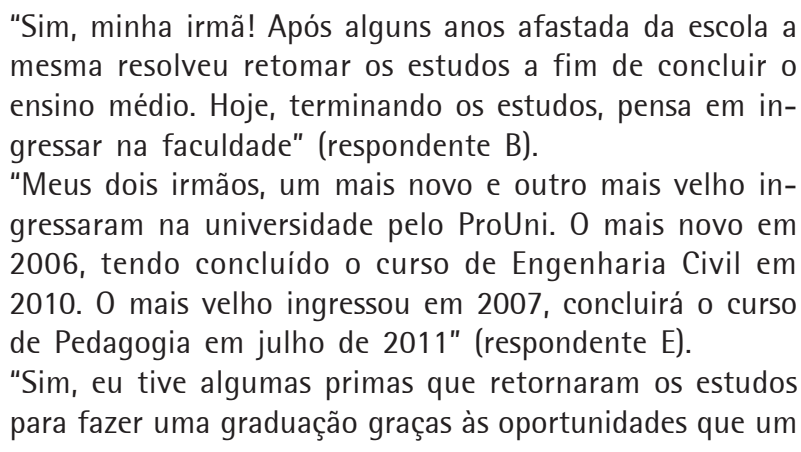


Curso superior me possibilitou" (respondente D).

"Minha irmã um ano mais velha do que eu começou a fazer o curso de Pedagogia, em São Paulo, quando soube que eu terminei a minha graduação" (respondente F).

Conforme a pesquisa realizada pelo Ibope a pedido do MEC, anteriormente destacada, o principal efeito da oportunidade de fazer uma graduação aconteceu nas famílias dos bolsistas do ProUni. Oito de cada dez entrevistados disseram que familiares se sentiram motivados a iniciar ou prosseguir os estudos. Ainda segundo a pesquisa, $97 \%$ dos entrevistados estão motivados a fazer especialização, mestrado ou doutorado

\title{
Você se sente motivado a continuar seus estudos em nível de pós-graduação?
}

De todos os respondentes cinco afirmaram que se sentiram motivados:

\begin{abstract}
"A pós-graduação irei fazer em breve, porém terminei há pouco tempo minha segunda graduação e estou fazendo cursos e certificações da área de Informática para aprimorar meus conhecimentos" (respondente D).

"Atualmente, estou matriculada em curso lato sensu e, em 2012, pretendo ingressar em um curso scrito sensu" (respondente E).

"Muito! Hoje, ainda estou na graduação. Resolvi complementar o que eu já aprendi anteriormente, mas logo pretendo ingressar em um curso de mestrado" (respondente B).

"Tenho muita vontade: só falta o recurso financeiro" (respondente C).

"Já conclui minha pós-graduação" (respondente A).
\end{abstract}

Um ex-bolsista não marcou essa resposta, porém justificou-se:

\begin{abstract}
"A esta resposta tenho que responder que às vezes tenho vontade, outras não, porque a pós-graduação que eu gostaria de fazer era a História da África, por causa do professor Anderson de Oliveira pois nas suas aulas eu viajava. E só encontrei na Candido Mendes, lá na cidade, e fica contramão para mim" (respondente F).
\end{abstract}

Ainda nos baseando em Bourdieu (1998), não se pode fazer com que os jovens oriundos das familias mais desprovidas economicamente tenham acesso aos diferentes niveis do sistema escolar e, em particular, aos mais elevados como o Ensino Superior, sem modificar profundamente o valor econômico e simbólico dos diplomas. Para o autor, os estudantes provenientes das famílias mais desprovidas economicamente e culturalmente têm todas as chances de obter, ao fim de uma longa escolaridade, muitas vezes paga com pesados sacrificios, um diploma desvalorizado; e, se fracassam, o que segue sendo seu destino mais provável, são votados a uma exclusão, sem dúvida, mais estigmatizante do que era no passa- 
do. 0 mesmo vale para o bolsista do ProUni que, apesar de não enfrentar elevados custos de mensalidade, também precisou se esforçar para conseguir e manter a bolsa na IES. Nesse sentido, é preciso estar atento, em termos de investimento de uma política pública como o ProUni, para que não tenhamos uma geração do que Bourdieu (1998) chamou de excluídos no interior, isto é, alunos com nível superior, porém, de baixa qualidade e com poucas chances de uma inserção de sucesso no mundo do trabalho em sua área de formação.

A pesquisa, apesar de suas limitações, permite inferir que a oportunidade de cursar o Ensino Superior através do ProUni pode contribuir para incluir uma população que não tinha sonhos ou planos de ingressar em faculdades e universidades e, dessa forma, colaborar para elevar sua autoestima, proporcionar o aumento da renda familiar e elevar as chances de alargamento do capital social. E, ainda, almejar que os filhos dos beneficiários do ProUni tenham maior probabilidade de frequentar a escola. Afinal, muitos estudos mostram que filhos de pais com maior escolaridade, independentemente da renda, tendem a atingir maior nivel educacional.

Apesar do aumento do número de ingressantes no Ensino Superior na última década, o abandono ou trancamento de matrículas nas IES é também um fenômeno em expansão. Entre 2001 e 2005, de acordo com cálculos feitos com base em dados do INEP, a taxa anual média de evasão no Ensino Superior brasileiro foi de $22 \%$, com pouca oscilação, mas mostrando tendência de crescimento. A evasão no ProUni, calculada pela primeira vez em 2006 pelo MEC, alcançou 15\%. Nesse contexto, observamos que os dados dos concluintes bolsistas do ProUni nas instituições pesquisadas se apresentam semelhantes à média de evasão no Ensino Superior brasileiro e próximos ao índice de evasão apresentado pelo MEC, em 2006.

Desde a sua implementação, o ProUni em 2011 bateu recorde de inscrições. Segundo balanço divulgado pelo MEC, em 26 de janeiro de 2011, o Programa Universidade para Todos registrou 1.048.631 inscrições. Apesar da demanda pelo Programa ter crescido $40 \%$, houve uma queda no número de bolsas concedidas e oferecidas. 0 programa cresceu a taxas de 18\% e 29\% em 2008 e 2009. Em 2010, porém, o número de selecionados recuou 5\%, para 152.691, quase 9.000 a menos do que no ano anterior (PROUNI..., 2001). A despeito das críticas que o ProUni vem recebendo no meio acadêmico (AMARAL; OLIVEIRA, 2011), estudo do Instituto de Pesquisa Econômica Aplicada (IPEA), divulgado em janeiro de 2011, aponta que para 73,4\% da população, o Programa Universidade para Todos deveria ser ampliado (SETE..., 2011). Conforme a pesquisa, entre os programas e ações que foram avaliados, o ProUni foi o que apresentou "maior visibilidade social".

\section{Algumas considerações}

A procura pelo magistério por alunos egressos do ensino médio não atravessa uma boa fase. Vale dizer que exercer a profissão docente não tem atraído a população jovem do país. Conforme dados do censo do Ensino Superior divulgado pelo MEC, em 
2010, no período de 2005 a 2009, o número de alunos que concluiu graduações em Pedagogia e Normal Superior caiu de 103 mil para 52 mil, o que comprova o desinteresse dos jovens pela carreira. Houve queda também nos graduandos em cursos de licenciaturas: em 2005 foram 77 mil, contra 64 mil em 2009. Os poucos jovens que se aventuram nos caminhos do magistério são egressos de camadas de baixa renda. $E_{\text {, }}$ mesmo assim, não há garantia alguma que, mesmo formado em uma licenciatura, 0 egresso irá atuar como docente na Educação Básica. Estudo realizado por Gatti e Barreto (2009), em que se toma por base o questionário socioeconômico do Exame Nacional de Cursos (ENADE), abrangendo 137.001 sujeitos, permite estabelecer relações entre as camadas menos favorecidas financeiramente e a procura pelas licenciaturas. A partir desse estudo, Gatti e Barreto (2009, p. 163) aponta que

entre os estudantes dos cursos de nível superior para a docência, 50,4\% situam-se nas faixas de renda familiar média, cujo intervalo é de três a dez salários mínimos. Ligeiras variações favorecem os estudantes das demais licenciaturas, em relação aos alunos de Pedagogia nas diferentes faixas salariais superiores. Observa-se, entretanto, uma clara inflexão em direção à faixa de renda mais baixa. É muito expressivo o percentual de alunos com renda familiar de até três salários mínimos $(39,2 \%)$ e escassa a frequência de sujeitos nas faixas de renda acima de dez salários mínimos.

Ainda segundo a autora, "no que se refere à bagagem cultural anterior, a escolaridade dos pais pode ser tomada como um indicador importante da bagagem cultural das familias de que provêm os estudantes" (GATTI; BARRETO, 2009, p. 163-164) e, finaliza, "pais e mães dos estudantes de Pedagogia são sistematicamente menos escolarizados que os dos demais cursos".

Tartuce, Nunes e Almeida (2010, p. 446) corroboram com o discurso de Gatti, ao afirmarem que "se divulga não só a tendência de queda na demanda pelas licenciaturas e no número de formandos, mas também a mudança de perfil do público que busca a docência".

Conforme o estudo das autoras,

se observou a tendência de mudança de perfil dos que buscam a profissão docente. A esse respeito, questiona-se: a escolha pela docência, por jovens das classes $C$ e $D$, será realmente uma opção? Ou é uma opção por descarte, quase uma desistência do que esse jovem realmente gostaria de fazer? Em geral, considera-se que a escolha se dê por descarte, por se tratar de cursos gratuitos ou baratos, aligeirados, de fácil acesso e, portanto, viáveis não só do ponto de vista econômico, mas também das exigências de natureza acadêmica (TARTUCE; NUNES; ALMEIDA, 2010, p. 475). 
A licenciatura, em muitos momentos, é uma escolha tardia feita pelo aluno e não uma escolha inicial, feita no concurso de acesso à instituição de Ensino Superior. Em muitos casos, nas IES públicas, a formação para a docência é buscada pelos alunos já na etapa final do curso de bacharelado o que se rotulou chamar de modelo $3+1$, isto é, três anos de bacharelado e um ano terminal de disciplinas pedagógicas e estágio supervisionado.

De acordo com Gatti (1996, p. 33 apud UNIVERSIDADE METODISTA DE PIRACICABA, 1998), as licenciaturas se apresentam como cursos hibridos em que parte dos conteúdos específicos não se articula com as disciplinas de cunho pedagógico, e estas se apresentam com um mínimo de disciplinas no cômputo geral do curso, não havendo como captar nessa estrutura híbrida uma perspectiva unificada que balize e articule todo currículo que é montado para uma determinada área.

Nesse sentido, a formação de professores ainda é compreendida como uma superposição de dois conjuntos de conhecimentos, ou como um verdadeiro apêndice à formação disciplinar. Essa estrutura vem encontrando, atualmente, dificuldades crescentes para cumprir seus objetivos face às profundas modificações no cenário educacional.

Outra questão relevante é a procura pelos cursos de licenciatura, bem menos acirrada quando comparada com outras áreas, que aponta para um relativo desprestígio da opção pelos cursos de formação de professores. Considerando o ensino público, enquanto a demanda para cursos com licenciatura é de cinco candidatos por vaga, para cursos de Economia é de seis, Administração, 11 e de Direito, 18 candidatos por vaga. Em Medicina ocorre a maior competição, com 41 candidatos por vaga.

Conforme Gatti e Barreto (2009, p. 68),

os estudantes que optam pela docência são, no entanto, relegados em sua esmagadora maioria aos cursos privados, que costumam apresentar menor qualidade acadêmica. $A$ oferta dos cursos de licenciatura permite inferir que as condições de formação dos professores no país, de modo geral, ainda estão muito distantes de serem satisfatórias, e evidencia que a preparação de docentes para os anos iniciais da escolaridade em nivel superior está sendo feita de forma um pouco mais precária que a dos demais. A atuação do poder público na formação de professores da educação básica tem cumprido até aqui uma função predominantemente complementar e redistributiva, a qual se concentra, sobretudo, no atendimento às regiões com menores indicadores de desenvolvimento econômico e social.

0 perfil dos alunos que buscam as licenciaturas mudou e vem mudando. Conforme apontado por Senapeschi (2004), a partir de dados da Diretoria de Estatísti- 
cas e Avaliação da Educação Superior do INEP apresentados na Revista Provão 2002, constatou-se que em cursos de formação de professores é maior a presença de alunos de faixas de renda mais baixas, que cursaram o ensino médio em escolas públicas e são filhos de pais com baixa escolaridade. Segundo o autor, "com esse perfil levantado pelo INEP, associado à inexistência de políticas públicas que garantam uma escola de qualidade para a classe trabalhadora, é que os alunos chegam às faculdades responsáveis pela formação de professores" (SENAPESCHI, 2004, p. 47).

Nesse caso, são muitas as indagações. 0 que foi causa e o que se configura como consequência? Será que a queda na qualidade da formação se dá pelo fato dos cursos de licenciatura estarem sendo procurados por alunos cujos pais têm baixa escolaridade e menor renda? E a consequência da má formação na Educação Básica leva o aluno a buscar os cursos menos disputados nos vestibulares, como é o caso das licenciaturas? Ou será que, por suspeitarem que não irão passar para os cursos mais concorridos, os alunos se contentam com um curso de nivel Superior mais rápido, mais barato e menos disputado?

Como afirmado anteriormente, as IES privadas concentram as matrículas de estudantes no Ensino Superior brasileiro e, consequentemente, são essas as instituições que vêm se responsabilizando pela formação de professores no Brasil, uma vez que são os cursos que demandam menor investimento material e de infraestrutura porque não requerem laboratórios, materiais outros que não sejam um professor, um quadro negro ou branco e uma apostila, termo comumente usado pelos alunos ao se referirem às cópias de textos utilizados pelos docentes.

Conforme afirmado por Gatti e Barreto (2009), a escolha da docência é uma espécde plano B ou "seguro desemprego", isto é, figura como uma alternativa no caso de não haver possibilidade de exercício de outra atividade. Segundo pesquisa realizada pelas autoras, apenas $2 \%$ dos estudantes do ensino médio tem como primeira opção no vestibular graduações relacionadas à atuação em sala de aula. No Sistema de Seleção Unificada (Sisu) de 2009, dos cem cursos com as notas de corte mais baixas, 75 são de licenciatura.

Reiterando o que já é amplamente conhecido na literatura e nas pesquisas sobre formação de professores no Brasil, no modelo universitário brasileiro, as licenciaturas ocupam um lugar secundário sendo que as universidades federais são responsáveis pela formação de somente $12 \%$ dos docentes que atuam hoje no pais. Diante desse quadro, a formação de professores é considerada atividade de menor categoria e quem a ela se dedica é pouco valorizado. Decorre daí uma ordem hierárquica na academia universitária, as atividades de pesquisa e de pós-graduação possuem reconhecimento e ênfase, a dedicação ao ensino e à formação de professores supõe perda de prestígio acadêmico (GATTI; BARRETO, 2009, p. 258-259). 
Retomando os dados da pesquisa realizada no bairro de Campo Grande observamos que os cursos concluídos pelos ex-bolsistas do Programa colocaram, no mercado de trabalho, 155 licenciados para atuar na Educação Básica.

Os dados do censo da Educação Superior e das pesquisas apontadas ao longo do presente trabalho confirmam a ausência de protagonismo e interesse das universidades públicas na formação de professores. 0 magistério não interessa aos alunos egressos das classes mais favorecidas; no entanto, aparece para os alunos das classes populares como uma forma de conseguir rápida inserção no mercado de trabalho antes do surgimento de alguma melhor oportunidade. Sendo o ProUni uma das portas de entrada das camadas de baixa renda no Ensino Superior, sendo as licenciaturas cursos rápidos, baratos e pouco procurados pelos jovens de classes mais favorecidas, indagamos: será o ProUni o novo protagonista de formação de professores?

Essa hipótese apresenta novos desafios: primeiramente a busca de dados quantitativos que a comprovem. Torna-se fundamental investigar a eficácia do Programa Universidade para Todos no que diz respeito ao número de concluintes e evadidos. Em segundo lugar são necessários estudos que relacionam os egressos do ProUni que cursaram licenciaturas e a atual situação de trabalho dessas populações. Estarão esses egressos atuando no magistério ${ }^{5} \mathrm{~A}$ escolha pela licenciatura foi efetivamente uma escolha ou seria uma "nova vocação" a partir da realidade tangivel do curso possível de ingressar e concluir? Por fim, vem o desafio mais importante que é zelar pela qualidade das licenciaturas oferecidas por IES privadas, em especial pelas faculdades que historicamente e legalmente não têm compromisso com a pesquisa tampouco com a extensão, mas com o ensino e nem sempre de qualidade e que estão em maior número no país. Um dos desmembramentos dessa pesquisa poderá ser analisar de forma qualitativa a atual situação de trabalho, renda e continuação da escolaridade desses primeiros bolsistas do Programa que concluiram cursos de licenciatura.

Como anteriormente destacado, em 2011, o ProUni recebeu número recorde de inscrições: 1.048.631 candidatos para 123.170 vagas e, segundo o MEC, o Programa está presente em pelo menos 1000 cidades brasileiras. 0 Ministro da Educação defendeu que o Senado faça uma alteração na lei que criou o ProUni para que a oferta seja exclusivamente de bolsas integrais. Para o primeiro semestre de $2011,4 \%$ do total de 123 mil bolsas oferecidas ficaram ociosas na primeira etapa de inscrições. De acordo com o MEC, quase $90 \%$ das 5.526 bolsas que não foram preenchidas são de cursos de educação a distância. Outra característica dessas vagas é que a maioria (87\%) é parcial. Entre as integrais, menos de 1\% não foi ocupado.

Finalizando, acreditamos que, como política de acesso ao Ensino Superior, o

5 0 Programa possui atualmente 462 mil bolsas em utilização e 116 mil estudantes com a graduação concluída como bolsistas do ProUni (BRASIL, 2010a). 
ProUni tem atingido seu público alvo: estudantes de baixa renda, com poucas chances de acesso ao Ensino Superior e que dificilmente seriam atendidos pelas IES públicas. No entanto, é preciso estar atento aos números, às estatísticas de atendimento, ao acompanhamento dessa política e, principalmente, aos egressos do Programa de modo que possam ser efetivadas mudanças, alterações e propostos novos rumos para o Programa na tentativa de tornar o Ensino Superior menos excludente, mais inclusivo e que seja possível ampliar a chegada de mais pessoas a esse nível de ensino sem perda de qualidade e sem desvio de recursos.

Acreditamos na necessidade de ouvir um grupo de atores de forma a contribuir para o entendimento do cenário das políticas de ensino superior, em especial, do ProUni: os egressos do programa, ou os destinatários dessa política pública. Concluímos sobre a necessidade de realização de estudos em larga escala no país sobre a situação dos egressos do Programa Universidade para Todos, em especial dos primeiros bolsistas do Programa.

Gostaríamos de destacar que os estudantes de classes populares muitas vezes não têm oportunidades de fazer escolhas sobre sua escolarização. A escolha pelo curso superior pode ser uma "não-escolha", isto é, já que ele não consegue entrar no curso desejado na instituição que gostaria de acessar, se contenta com o que tem: um curso menos procurado, menos valorizado, em uma IES menos prestigiada. Logo, esses estudantes irão construir trajetórias escolares meio ao "acaso" e, como afirma Bourdieu (1998, p. 223), terão que encontrar seu caminho em um universo cada vez mais complexo e são, assim, levados a investir na hora errada e no lugar errado, em um capital cultural, no final das contas, extremamente reduzido. Conforme o autor, o capital cultural é um conceito que explicita um novo tipo de capital, um novo recurso que poderá fazer com que o indivíduo se destaque em especial em uma sociedade em que a posse desse recurso é privilégio de poucos. Cabe destacar que, entre a população adulta brasileira (de 25 a 64 anos), apenas 11\% são detentores de diploma de Nivel Superior ${ }^{6}$. Nesse contexto, o ProUni tem possibilitado a inclusão de excluídos. No entanto, é extremamente necessário e fundamental investigar se não estamos gerando novos excluídos com certificação em Nível Superior.

6 "Levantamento feito pelo especialista em análise de dados educacionais Ernesto Faria, a partir de relatório da Organização para a Cooperação e o Desenvolvimento Econômico (OCDE), coloca o Brasil no último lugar em um grupo de 36 países ao avaliar o percentual de graduados na população de 25 a 64 anos. Os números se referem a 2008 e indicam que apenas $11 \%$ dos brasileiros nessa faixa etária têm diploma universitário. Entre os países da OCDE, a média (28\%) é mais do que o dobro da brasileira” (CIEGLINSKI, 2011, não paginado). 


\section{Referências}

ALMEIDA, S. C. de. 0 avanço da privatização na educação brasileira: o ProUni como uma nova estratégia para a transferência de recursos públicos para o setor privado. 2006. Dissertação (Mestrado)-Programa de Pós-Graduação em Educação, Universidade Federal Fluminense, Niterói, 2006.

AMARAL, D. P. do; OLIVEIRA, F. B. de. 0 ProUni e a conclusão do ensino superior: questões introdutórias sobre os egressos do programa na zona oeste do Rio de Janeiro. Ensaio: avaliação e políticas públicas em educação, Rio de Janeiro, v. 19, n. 70, jan./mar. 2011.

BARRETTO, Elba Siqueira de Sá. Perspectivas teóricas e metodológicas da pesquisa em politica educacional na atualidade. In: SEMINÁRIO DE AVALIAÇÃO DO PDE EDUCAÇÃO BÁSICA E INTERCÂMBIO DE PESQUISA CIENTÍFICA, 2008, Brasília. Trabalhos apresentados... Brasilia, DF: Anped, 2008.

BOLSAS para ninguém. 0 Globo, Rio de Janeiro, 13 mar. 2011. 0 País, p. 3.

BOURDIEU, P. Escritos de educação. 8. ed. Petrópolis: Vozes, 1998.

BRASIL. Lei nº. 9.394, de 20 de dezembro de 1996. Estabelece as diretrizes e bases da educação nacional. Diário Oficial [da] República Federativa do Brasil, Brasília, DF, 23 dez. 1996.

. Lei $n^{\circ}$. 11.096, de 13 de janeiro de 2005. Institui o Programa Universidade para Todos - PROUNI, regula a atuação de entidades beneficentes de assistência social no ensino superior; altera a Lei n ${ }^{0} 10.891$, de 9 de julho de 2004, e dá outras providências. Diário Oficial da União, Brasília, DF, 14 jan. 2005. Disponível em: <www.planalto.gov.br/ccivil_03/_ato2004-2006/.../Lei/ L11096.htm>. Acesso em: 31 out. 2011.

Ministério da Educação. Balanço da gestão da educação 2003-2010. Brasília, DF, 2010a. Disponível em: <http://gestao2010.mec.gov.br/>. Acesso em: 17 nov. 2010.

Ministério da Educação. Sinopse das ações do Ministério da Educação. Brasília, DF, 2010b. Disponivel em: <gestao2010.mec.gov.br/download/ sinopse_acoes_mec.pdf>. Acesso em: 3 nov. 2011.

CIEGLINSKI, A. Pesquisa sobre população com diploma universitário deixa o Brasil em último lugar entre 36 países. Agência Brasil, Brasilia, DF, 22 abr. 2011. Disponivel em: <http://educacao.uol.com.br >. Acesso em: 3 nov. 2011. 
GATTI, B. A.; BARRETTO, E. S. S. Professores do Brasil: impasses e desafios. Brasília, DF: Unesco, 2009.

IBGE. Pesquisa Nacional por Amostra de Domicilios 2009. Rio de Janeiro, 2010. Disponível em: <http://www.ibge.gov.br/home/estatistica/populacao/ trabalhoerendimento/pnad2009/default.shtm>. Acesso em: 22 fev. 2011.

INEP. Censo de educação superior 2009. Brasília, DF, 2010. Disponível em: <http://censosuperior.inep.gov.br/resumos-tecnicos>. Acesso em: 27 out. 2011.

INSCRIÇÕES no ProUni superaram expectativas, diz Ministério da Educação. Folha on line, São Paulo, 2011. Disponível em: <http://www1.folha.uol.com.br/ folha/educacao/ult305u18224.shtml>. Acesso em: 27 out. 2011.

LUNA, S. V. de. Planejamento de pesquisa: uma introdução. São Paulo: Educa, 1997.

MINAYO, M. C. (Org.). Pesquisa social: teoria, método e criatividade. 25. ed. Petrópolis: Vozes, 2007.

NUNES, E. Desafio estratégico da política pública: o ensino superior brasileiro. Revista de Administração Pública, Rio de Janeiro, p. 103-47, 2007. Edição especial comemorativa.

OTRANTO, C. R. A reforma da educação superior do Governo Lula: da inspiração à implantação. In: SILVA JÚNIOR, J. dos R.; OLIVEIRA, J. F. de; MANCEBO, D. (Org.). Reforma universitária: dimensões e perspectivas. Campinas: Alínea, 2006.

PERELMAN, C. Retóricas. São Paulo: Martins Fontes, 1999.

PROUNI encolhe, apesar da procura ter crescido. Folha de S. Paulo, São Paulo, 11 fev. 2011.

RIO DE JANEIRO (RJ). Prefeitura. Armazém de dados. Rio de Janeiro, 2010. Disponível em: <http://www.armazemdedados.rio.rj.gov.br>. Acesso em: 14 nov. 2010.

SCHWARTZMAN, J.; SCHWARTZMAN, S. O ensino superior privado como setor econômico. [S. I.], 2002. Disponível em: <http://biblioteca.planejamento.gov.br/ biblioteca-tematica-1/textos/educacao-cultura/texto-98-2013-0-ensinosuperior-privado-como-setor-economico.pdf>. Acesso em: 27 out. 2011.

SENAPESCHI, A. N. Trazendo para debate a preocupação com a formação dos professores para o ensino básico. Revista Brasileira de Estudos Pedagógicos, Brasília, DF, v. 85, n. 209/210/211, p. 45-55, jan./dez. 2004. 
SETE em cada dez brasileiros querem ampliação do ProUni. Correio Braziliense, Brasília, DF, 28 fev. 2011.

SGUISSARDI, V. Modelo de expansão da educação superior no Brasil: predomínio privado/mercantil e desafios para a regulação e a formação universitária.

Educação e Sociedade, Campinas, SP, v. 29, n. 105, p. 991-1022, set./dez. 2008.

SOUZA, C. Políticas públicas: uma revisão da literatura. Sociologias, Porto Alegre, v. 8, n. 16, p. 20-45, jul./dez. 2006.

TARTUCE, G. L. B.; NUNES, M. M. R.; ALMEIDA, P. C. A. de. Alunos do ensino médio e atratividade da carreira docente no Brasil. Cadernos de Pesquisa, São Paulo, v. 40, n.140, p. 445-477, maio/ago. 2010.

TEIXEIRA, E. As três metodologias: acadêmica, da ciência e da pesquisa.

Petrópolis, RJ: Vozes, 2005.

UNIVERSIDADE METODISTA DE PIRACICABA. Politica para as licenciaturas da UNIMEP. 2. ed. Piracicaba: Ed. Unimep, 1998. (Série Institucional, n. 5).

ZAG0, N. Processos de escolarização nos meios populares: as contradições da obrigatoriedade escolar. In: NOGUEIRA, M. A.; ROMANELLI, G.; ZAGO, N. (Org.). Família e escola. 5. ed. Petrópolis: Vozes, 2010. p. 19-43.

Recebido em: 20/07/2011

Aceito para publicação em: 28/10/2011 